\title{
Tinjauan Fiqh Muamalat dan Hukum Nasional tentang Wakaf di Indonesia
}

\author{
Oleh: Ali Amin Isfandiar ${ }^{*}$
}

\begin{abstract}
Waqf is one of philanthropy institutions in Islam. Debates on which have been coloring of dynamical thought of Islam law, occurred since classical Islamic scholar until modern one. Topics is concerning with existence of waqif, mauquf'alaih (nadzir), mauquf (object), and sighat (proclamation). Figh and Indonesian rule, called UU (red. Act) are giving deepest attention and analysis. The latest makes combination and accommodation to reconstruct and widen of the implementation scope of waqf. It is due to reinterpretation derived from earliest concept, and public welfare reached is as final objective of its philanthropy based on new interpretation. This paper is also going to elaborate some new issues like cash waqf (waqf al-nuqud) dan productive waqf, emerged from lack of professionalism and mismanagement of waqf object. These elaborations presented to analysis content substance of the Act 41/2004 as compromised solution conducted by the Rule.
\end{abstract}

Kata Kunci: waqh al-nuqud, filantropi, dan wakaf produktif

\section{Pendahuluan}

Islam menampilkan dirinya sebagai agama yang berwajah filantropis. ${ }^{1}$ Wujud filantropi digali dari doktrin keagamaan yang bersumber dari al-Qur'an dan Hadits yang dimodifikasi dengan perantara mekanisme ijtihad sehingga

*Penulis adalah dosen STAIN Pekalongan, peserta Program Doktor Ekonomi Islam UIN Sunan Kalijaga Yogyakarta. Emai: alminist@yahoo.com.sg

${ }^{1}$ Istilah filantropi (pbilantbropy) berasal dari bahasa Yunani, philos (cinta) dan antbropos (manusia), yang secara harfiah diartikan sebagai konseptualisasi dari praktik memberi (giving), pelayanan (service) dan asosiasi (association) dengan sukarela untuk membantu pihak lain yang membutuhkan sebagai ekspresi rasa cinta. Secara umum didefinisikan sebagai tindakan sukarela untuk kepentingan publik (voluntary action for the public goods). Lihat Andi Agung Prihatna (2005). "Filantropi dan Keadilan Sosial di Indonesia". dalam Chaider S. Bamualim dan Irfan Abubakar. Revitalisasi Filantropi Islam: Studi Kasus Lembaga Zakat dan Wakaf di Indonesia. (Jakarta: Pusat Bahasa dan Budaya UIN Syahid), hlm. 3-4. 
institusi zakat, infak, sadakah, dan wakaf muncul. Institusi yang disebut terakhir, yaitu wakaf terus mengalami perkembangan paradigma yang cukup signifikan seiring dengan penyesuaian berbagai aturan yang bersifat ijtihadi dan penerapan wakaf di wilayah tertentu dengan dimensi sejarah yang selalu berubah.

Dalam sejarahnya, wakaf merupakan instrumen maliyah, yang sebagai ajaran ia tergolong pada syariah yang bersifat sakral dan suci, tetapi pemahaman dan implementasi wakaf tersebut tergolong pada fiqh (upaya yang bersifat kemanusiaan); karena itu, bisa dipahami bahwa praktik dan realisasi wakaf tersebut terkait erat dengan realitas dan kepentingan umat di masing-masing negara muslim (termasuk Indonesia). ${ }^{2}$

Di beberapa negara, wakaf secara serius dijadikan sebagai media untuk mensejahterakan rakyat di samping pendapatan negara yang lain. Kekekalan objek wakaf menjadi salah satu doktrin utama untuk melestarikan keberadaannya dan modifikasi pemanfaat yang bervariasi menjadi inovasi pemberdayaan harta wakaf sehingga tidak statis dan stagnan. Wakif mengalami perubahan bentuknya, tidak hanya wakif perorangan tetapi juga wakif lembaga (baca: badan hukum), yang dituntut kredibilitas dan akuntabilitasnya. Demikian pula dengan keberadaan nadzir yang profesional menjadi pilihan dan keniscayaan zaman modern sekarang ini dalam mengemban amanat untuk mengelola harta wakaf.

Hal-hal tersebut yang menjadi fokus kajian pada tulisan ini yang lebih rinci disebar dalam sub kajian mengenai wakaf ditinjau dari fiqh muamalah, wakaf ditinjau dari hukum nasional, transformasi aturan wakaf dari fiqh ke hukum nasional, dan implikasi sosial wakaf yang muncul dari aturan hukum yang ditetapkan di Indonesia.

Sebagai acuan dalam pembacaan tulisan ini, penulis memberikan catatan bahwa tulisan ini tidak akan memperbincangkan perdebatan tentang keberadaan istilah fiqh secara umum, tetapi terkonsentrasi pada wacana fiqh klasik tentang wakaf dan hal-hal yang terkait. Hukum nasional yang dimaksud adalah semua aturan yang dibuat oleh aparatur negara, baik pemerintah maupun Dewan. Tetapi fokus hukum nasional yang dianalisis dalam tulisan ini adalah UU No. 41 tahun 2004 tentang wakaf, meskipun tidak menutup kemungkinan juga mengambil aturan hukum nasional yang lain. Tulisan ini menggunakan pendekatan deskriptif referensial dengan nuansa kajian fiqh muamlat dan hukum Islam, yang selalu mengalami perubahan seiring dengan bersentuhannya institusi wakaf dengan realitas sehingga keniscayaan munculnya ijtihad baru tak terelakkan.

${ }^{2}$ Akh. Minhaji (2005). "Nation State dan Implikasinya Terhadap Pemikiran dan Implementasi Hukum Wakaf”, Kata Pengantar dalam Abdul Ghofur Anshori, Hukum dan Praktik Perwakafan di Indonesia, (Yogyakarta: Pilar Media), hlm. xxi. 


\section{Wakaf: Tinjauan Fiqh Muamalat}

Wakaf dilihat dari sudut fiqh mengalami perbincangan yang sangat menarik, meskipun terkadang objek perbincangannya lebih menitikberatkan pada unsur wakaf. Menariknya pula baik ulama klasik maupun modern tidak akan lepas dari kajian tersebut. Secara sistematis sub bab ini mengkaji pengertian, dasar hukum, unsur (rukun), bentuk-bentuk wakaf.

\section{Pengertian Wakaf}

Kata wakaf atau waqf (الوقف) berasal dari bahasa Arab yang berasal dari akar kata wa-qa-fa (وقف) berarti menahan, berhenti, diam di tempat atau berdiri. Kata waqafa-yaqifu-waqfan semakna dengan kata habasa-yabbisu-tabbisan maknanya terhalang untuk menggunakan. Kata waqf dalam bahasa Arab mengandung makna: (الوقف بمعنس التحبيس التسبيل), artinya: menahan, menahan harta untuk diwakafkan, tidak dipindahmilikkan. ${ }^{3}$

Dalam bahasa Arab, istilah wakaf kadang-kadang bermakna objek atau benda yang diwakafkan (al-mauquf bib) atau dipakai dalam pengertian wakaf sebagai institusi seperti yang dipakai dalam perundang-undangan Mesir. Di Indonesia, term wakaf dapat bermakna objek yang diwakafkan atau institusi. ${ }^{4}$

Menurut istilah meskipun terdapat perbedaan penafsiran, disepakati bahwa makna wakaf adalah menahan dzatnya benda dan memanfaatkan hasilnya atau menahan dzatnya dan menyedekahkan manfaatnya. ${ }^{5}$ Adapun perbedaan pendapat para ulama fiqh dalam mendefinisikan wakaf diakibatkan cara penafsiran dalam memandang hakikat wakaf. Perbedaan pendangan tersebut dapat diuraikan sebagai berikut: ${ }^{6}$

\section{A. Abu Hanifah}

"Wakaf adalah menahan suatu benda yang menurut hukum, tetap miliki si wakaf dalam rangka mempergunakan manfaatnya untuk kebajikan." Berdasarkan

\footnotetext{
${ }^{3}$ Muhammad ibn Bakar ibn Mandzur al-Mishri (1301 H). Lisan al-'Arab. (Bulaq: AlMishriyah,), Jilid 11, hlm. 276; Wahbah Zuhaili (1985). Al-Figh al-Islamiy wa 'Adillatubu. (Mesir: Dar al-Fikr al-Mu'ashir), hlm. 7599.

${ }^{4}$ Juhaya S. Praja (1995). Perwakafan di Indonesia: Sejarah, Pemikiran, Hukum dan Perkembangannya. (Bandung: Yayasan Piara), hlm. 6.

${ }^{5}$ Abu Zahrah (1971). Muhadharat fi al-Waqf. (Beirut: Dar al-Fikr al-'Arabi), hlm. 41.

${ }^{6}$ Wahbah Zuhaili. Al-Fiqh al-Islamiy, hal. 7599-7502; Muhammad Abid Abdullah Al-Kabisi (2004). Hukum Wakaf: Kajian Kontemporer Pertama dan Terlengkap tentang Fungsi dan Pengelolaan Wakeaf serta Penyelesaian atas Sengketa Wakaf, Terj. Ahrul Sani Faturrahman \& Rekan KMCP. (Jakarta: Dompet Dhuafa Republika \& IIMaN), hlm. 38-60.
} 
definisi itu maka pemilikan harta wakaf tidak lepas dari si wakif, bahkan ia dibenarkan menariknya kembali dan ia boleh menjualnya. Jika si wakif wafat, harta tersebut menjadi harta warisan buat ahli warisnya. Jadi yang timbul dari wakaf hanyalah "menyumbangkan manfaat". Karena itu madzhab Hanafiyah mendefinisikah "wakaf adalah tidak melakukan suatu tindakan atas suatu benda, yang berstatus tetap sebagai hak milik, dengan menyedekahkan manfaatnya kepada suatu pihak kebajikan (sosial), baik sekarang maupun akan datang”.

\section{B. Madzhab Maliki}

Madzhab Maliki berpendapat bahwa wakaf itu tidak melepaskan harta yang diwakafkan dari kepemilikan wakif, namun wakaf tersebut mencegah wakif melakukan tindakan yang dapat melepaskan kepemilikannya atas harta tersebut kepada yang lain dan wakif berkewajiban menyedekahkan manfaatnya serta tidak boleh menarik hartanya untuk digunakan oleh mustahiq (penerima wakaf), walaupun yang dimilikinya itu berbentuk upah, atau menjadikan hasilnya untuk dapat digunakan seperti mewakafkan uang. Wakaf dilakukan dengan mengucapkan lafadz wakaf untuk masa tertentu sesuai dengan keinginan pemilik. Dengan kata lain, pemilik harta menahan benda itu dari penggunaan secara kepemilikan, tetapi membolehkan pemanfaatan hasilnya untuk tujuan kebajikan, yaitu pemberian manfaat benda secara wajar sedang benda itu tetap milik si wakif. Perwakafan itu berlaku untuk suatu masa tertentu, dan karenanya tidak boleh disyaratkan sebagai wakaf kekal (selamanya).

\section{Madzhab Syafi'iyah, Hanbaliyah dan sebagian Hanafiyah}

Madzhab ini berpendapat bahwa wakaf adalah mendayagunakan harta untuk diambil manfaatnya dengan mempertahankan dzatnya benda tersebut dan memutus hak wakif untuk mendayagunakan harta tersebut. Wakif tidak boleh melakukan apa saja terhadap harta yang diwakafkan. Berubahnya status kepemilikan dari milik seseorang, kemudian diwakafkan menjadi milik Allah. Jika wakif wafat, harta yang diwakafkan tersebut tidak dapat diwarisi oleh ahli waris. Wakif menyalurkan manfaat harta yang diwakafkannya kepada mauquf alaih (orang yang diberi wakaf) sebagai sedekah yang mengikat, di mana wakif tidak dapat melarang menyalurkan sumbangannya tersebut. Apabila wakif melarangnya, maka qadhi berhak memaksanya agar memberikannya kepada mauquf alaih. Karena itu madzhab ini mendefinisikan wakaf adalah tidak melakukan suatu tindakan atas suatu benda, yang berstatus sebagai milik Allah swt, dengan menyedekahkan manfaatnya kepada suatu kebajikan (sosial). 


\section{Dasar hukum wakaf}

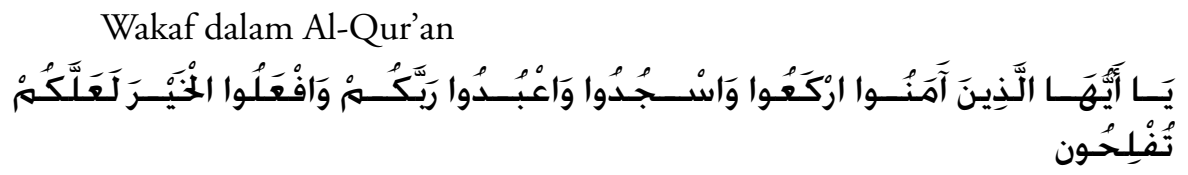

"Hai orang-orang yang beriman, rukulah kamu, sujudlah kamu, sembahlah Tuhanmu dan perbuatlah kebajikan, supaya kamu mendapat kemenangan". (QS. Al-Hajj (22): 77)

Kata khair (kebaikan) yang secara umum dimaknai salah satunya dalam bentuk memberi seperti wakaf, dan berlaku untuk bentuk-bentuk charity atau endowment yang lain yang bersifat filantropi, tentunya dalam ajaran Islam.

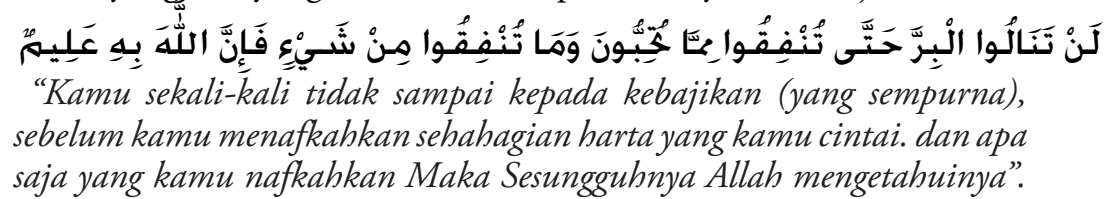

(QS. Ali Imran (3): 92)

Berbeda dengan kata khair (kebaikan), kata birr (kebaikan) terkait erat dengan kata infaq (memberi). Kata birr ini terletak antara huruf lan (mengandung makna tidak untuk selamanya) dan hatta (hingga atau sampai yang berhubungan dengan tindakan). Sehingga ada 3 kata kunci pada ayat ini sehingga sering kali dijadikan dalil utama dalam wakaf yang bersumber dari al-Qur'an, (1) kebaikan, (2) tindakan infak, dan (3) harta yang dimiliki adalah paling dicintai. Psikoanalisis mengatakan tidak mungkin orang memberikan harta yang paling dicintai kepada orang lain demi kebaikan. Salah satu analisis itulah sehingga kebaikan dalam konteks kata birr sulit untuk dilakukan. Oleh para penafsir model infak seperti ini, digolongkan sebagai wakaf, bukan bentuk pemberian yang lain.

Wakaf dalam Hadis

Ada beberapa hadis yang dianalisis menjelaskan tentang wakaf. Hadis-hadis tersebut antara lain:

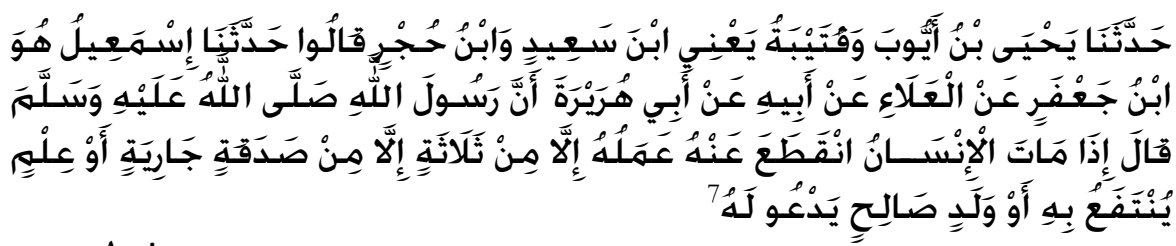

Artinya:

“..... dari Abi Hurairah r.a. sesunggunya Rasulullah Saw berkata: jika seseorang telah meninggal dunia, maka terputuslah semua amal dari dirinya kecuali tiga, yaitu sadakah jariyah, ilmu yang bermanfaat dan anak saleh yang mendoakan kepadanya (kepada orang tuanya)".

${ }^{7}$ Muslim (t.t.). Shahih Muslim. (Mesir: Dar al-Fikr al-Mu'ashir), Juz 8, hlm. 405. 
Para ahli hadis dan kebanyakan ahli fiqh mengidentifikasi bahwa wakaf termasuk sadaqah jariyah, kecuali al-Dzahiri. Dalam hadis tersebut bahwa sadaqah jariyah direalisasikan dalam bentuk wakaf yang pahalanya mengalir terus menerus kepada si wakif.

Hadis yang lebih tegas menggambarkan dianjurkannya wakaf, yaitu hadis riwayat Ibn Umar tentang tanah khairbar. Berikut bunyi hadis tersebut:

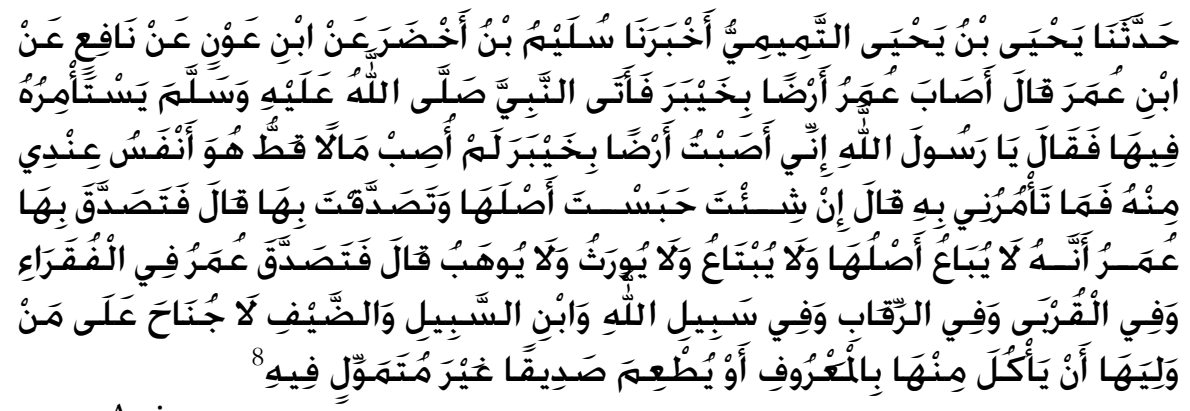

Artinya:

"..... dari Ibnu Umar ra berkata, bahwa sahabat Umar ra memperoleh sebidang tanah di Khaibar, kemudian menghadap kepada Rasulullah untuk memohon petunjuk. Umar berkata: ya Rasulullah, saya mendapatkan sebidang tanah di Khaibar, saya belum pernah mendapatkan harta sebaik itu, maka apakah yang engkau perintahkan kepadaku? Rasulullah menjawab: bila kamu suka, kamu tahan (pokoknya) tanah itu, dan kamu sedekahkan (hasilnya). Kemudian Umar melakukan shadaqah, tidak dijual, tidak dibibahkan dan tidak pula diwariskan. Ibnu Umar berkata: Umar menyedekahkankannya kepada orang fakir, kaum kerabat, bidak belian, sabilillah, ibn sabil dan tamu. Dan tidak dilarang bagi orang yang menguasai tanah wakaf itu (mengurus) untuk makan dari hasilnya dengan cara baik (sepantasnya) atau makan dengan tidak bermaksud menumpuk harta".

Ada perbedaan kosa kata periwayatan pada akhir matan hadis yaitu

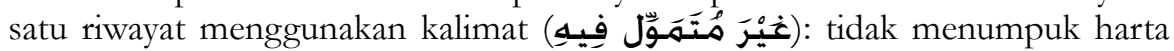
atau tidak berlebih-lebihan (sesuai dengan kebutuhan) dan ada riwayat yang

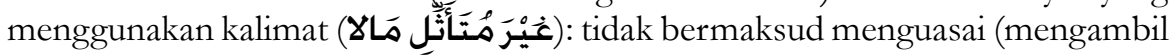
alih kepemilikan). Tetapi intinya sama mengendalikan batasan tingkat dan porsi konsumsi nadzir.

Dari hadis inilah muncul berbagai penafsiran yang secara substantif memperbincangkan (1) Esensi wakaf, antara dzat benda dan manfaat benda, (2) status kepemilikan harta wakaf, (3) konsekuensi kepemilikan memunculkan 3 larangan yang mengiringi perlakuan terhadap benda wakaf, yaitu tidak boleh dijual, dihibahkan, dan diwariskan, (4) kemestian adanya nadzir, yang memiliki

\footnotetext{
${ }^{8}$ Ibid., hlm. 407.
} 
hak konsumsi, dengan syarat tidak berlebihan dan tidak bermaksud mengambil alih kepemilikan, (5) benda bergerak dan tidak bergerak, yang belakangan memunculkan wacana wakaf tunai, dan (6) wakaf permanen dan wakaf temporal.

\section{Unsur (Rukun) wakaf}

Wakaf dinyatakan sah apabila telah terpenuhi rukun dan syaratnya. Rukun wakaf menurut fiqh ada 4 (empat) macam, yaitu (1) waqif (orang yang mewakafkan), (2) Mauquf'alaih (pihak yang diserahi wakaf), (3) Mauquf (harta yang diwakafkan), (4) Shighat atau iqrar (pernyataan atau ikrar wakif sebagai suatu kehendak untuk mewakafkan). ${ }^{9}$

\section{A. Waqif (orang yang mewakafkan)}

Wakif adalah pihak yang mewakafkan. Wakif harus mempunyai kecakapan hukum atau kamalul ahliyah (legal competent) dalam membelanjakan hartanya (tasharrufal-mal). Kecakapan tersebut meliputi 4 kriteria, ${ }^{10}$ yaitu: (1) Merdeka; (2) Berakal sehat, (3) Dewasa (baligh), (4) tidak dibawah pengampuan. ${ }^{11}$

Berkenaan dengan pelepasan benda wakaf oleh wakif muncul perbedaan pendapat tentang status kepemilikan benda yang sudah diwakafkan. Kepemilikan, hanya Abu Hanifah yang mengatakan bahwa harta yang diwakafkan adalah tetap milik si wakif. Pendapat ini berimplikasi pada kewenangan wakif untuk mentasharuf-kan harta wakaf sesuai dengan keinginannya, termasuk menghibahkan, menjual dan mewariskan. Ia memandang bahwa wakaf itu seperti ariyah (pinjam meminjam), di mana benda di tangan peminjam sebagai pihak yang mengambil manfaat benda tersebut. Menurutnya wakaf mempunyai kepastian hukum hanya dalam tiga hal: (1) wakaf masjid, (2) wakaf bila diputuskan oleh hakim, (3) bila benda wakaf dihubungkan dengan kematian si wakif yaitu wakaf wasiat. ${ }^{12}$ Selain Abu Hanifah, Imam Malik juga berpendapat sama bahwa harta wakaf masih milik si wakif. Pendapat inilah yang mempengaruhinya hingga ada pembedaan antara wakaf muabbad dan wakaf muaqqat. Bila muabbad kepemilikan putus, maka muaqat kepemilikan masih pada wakif. ${ }^{13}$ Berdasarkan hadis Umar, Imam Malik memandang bahwa tidak

${ }^{9}$ Asy-Syarbini (t.t.). Mughni al-Mubtaj, (Kairo: Mushthafa Halabi), Juz II, hlm. 376.

${ }^{10}$ Ibid.

${ }^{11}$ Di bawah pengampuan menurut al-Bajuri meliputi 2 jenis yaitu (1) orang yang berhutang, dan (2) orang yang sedang sakit parah (penyakit cenderung mematikan). Lihat al-Baijuri (t.t.). Hasyiyah al-Baijuri. (Beirut: Dar al-Fikr), II, hlm. 44.

${ }^{12}$ Wahbah Zuhaili. Al-Fiqh al-Islamiy, hlm. 153.

${ }^{13}$ Pandangan ini yang dijadikan dasar dalam UU No. 41 Tahun 2004 yang membolehkan wakaf untuk jangka waktu tertentu atau muaqqat. 
ada indikasi dari hadis tersebut yang menyuruh wakaf untuk selamanya, sehingga Imam Malik memunculkan pembagian tersebut. Selain dua pendapat tersebut hampir semua sepakat terhadap putusnya kepemilikan antara harta wakaf dengan wakif dan berpindahnya kepemilikan menjadi milik Allah. Syafii menyamakan wakaf dengan al-itq (pemerdekaan budak). Budak adalah milik tuannya, tetapi bila ia sudah merdeka, ia menjadi milik Allah. ${ }^{14}$

\section{B. Mauquf'alaih (orang yang diberi amanat wakaf)}

Mauquf 'alaih dalam literatur fiqh kadang diartikan orang yang diserahi mengelola harta wakaf, yang sering disebut nadzir, kadang juga diartikan peruntukan harta wakaf. Bila diartikan mauquf 'alaih sebagai nadzir, dalam literatur fiqh kurang mendapat porsi pembahasan yang detail oleh para ahli fiqh yang terpenting adalah keberadaan mauquf 'alaih mampu mewujudkan peruntukan benda wakaf (makna lain dari mauquf'alaih). Hal ini terpengaruh oleh unsur tabarru' (kebaikan) yang meliputi peruntukan ibadah dan sosial (umum) kecuali yang bertentangan dengan Islam (ideologi) dan maksiat. Pengaruh lain adalah karena pemahaman bahwa wakaf termasuk akad sepihak yang tidak membutuhkan adanya qabul dan salah satu pendapat boleh hukumnya wakaf kepada diri sendiri.

Berkenaan dengan keyakinan nadzir, menurut Nawawi ${ }^{15}$ sah hukumnya wakaf kepada kafir dzimmi dengan 2 syarat, (1) peruntukan objek wakaf yang diamanatkan kepada nadzir tidak berupa ibadah bagi muslim, seperti wakaf Qur'an kepada nadzir kafir dzimmi, dan (2) manfaat benda wakaf oleh nadzir tidak untuk kepentingan keyakinan si kafir dzimmi seperti wakaf untuk pembangunan gereja yang difasilitasi oleh nadzir kafir dzimmi.

\section{Mauquf(Harta Benda Wakaf)}

Perbincangan fiqh mengenai benda wakaf, bertolak pada, pertama, jenis harta, apakah benda bergerak atau tidak bergerak, atau bisa keduanya. Madzhab Syafi'iyah dan Hanbaliyah tergolong konservatif dengan hanya membolehkan harta tak bergerak sebagai objek wakaf. Sementara Hanafiyah dan Malikiyah cenderung membolehkan wakaf harta bergerak. Perbedaan ini muncul dari perbedaan menafsirkan apakah yang diwakafkan adalah dzat benda atau manfaat benda. Bila dzat benda maka cenderung benda tidak bergerak yang ternyata

${ }^{14}$ Wahbah Zuhaili. Al-Figh al-Islamiy, hlm. 7599-7502; Al-Kabisi. Hukum Wakaf, hlm. 38-60; Abu Zahrah. Muhadharat fi al-Waqf, hlm. 34; Ali Fikri (1938). Al-Mu'amalat al-Maliyah wa al-Adabiyah. (Mesir: Mushthafa al-Babi al-Halabi), hlm. 311.

${ }^{15}$ Nawawi (t.t.). al-Raudhah. (Beirut: Dar al-Kutub al-'Ilmiah), Juz IV, hlm. 379. 
jumlah jenisnya sedikit, sedangkan bila manfaat benda cenderung benda bergerak yang jumlah jenisnya sangat banyak.

Keterkaitan antara status kepemilikan wakif terhadap benda wakaf setelah diwakafkan berimplikasi pada kewenangan atas perlakuan wakif terhadap benda wakaf tersebut yang oleh hadis riwayat umar memuat tiga tindakan yaitu dijual, dihibahkan dan diwariskan. Terhadap hal tersebut Abu Hanifah menyatakan bahwa harta wakaf masih milik wakif, maka wakif boleh memperlakukan apa saja terhadap harta wakaf seperti menjual, menghibakan, dan mewariskan termasuk mengagunkan harta benda wakaf. berbeda dengan Hanafi, Maliki sekalipun menyatakan bahwa harta wakaf milik wakif, tetapi wakif tidak punya hak untuk mendayagunakan harta wakaf secara pribadi dalam bentuk apapun. Sedangkan Syafii dan Hanbali menyatakan putusnya kepemilikan harta wakaf dengan wakif sehingga wakif terputus haknya terhadap harta wakaf. Kedua, kelanggengan atau keabadian objek wakaf yang terkait erat dengan objek wakaf yang bergerak. Oleh karena itu mewakafkan harta bergerak harus melekat dengan harta tak bergerak seperti wakaf alat pertanian terkait dengan sawah, dan sebagainya. ${ }^{16}$

Hal yang menarik lagi adalah perubahan peruntukan. Jika suatu ketika benda wakaf itu sudah tidak ada manfaatnya atau sudah berkurang manfaatnya, kecuali ada perubahan pada benda wakaf tersebut, seperti menjual, merubah bentuk asal, memindahkan ke tempat lain, atau menukar dengan benda lain, bolehkan perubahan itu dilakukan terhadap benda wakaf tersebut? Ternyata dalam hal tersebut para ulama fiqh berbeda pendapat.

Sebagian ulama berpendapat bahwa kalau benda wakaf sudah tidak berfungsi (tidak dapat dipergunaka) atau kurang berfungsi, maka benda tersebut tidak boleh dijual, tidak boleh diganti/tukar, tidak boleh dipindahkan, tapi benda tersebut dibiarkan tetap dalam keadaannya. Pendapat ini adalah pendapat yang dikemukakan oleh Syafi'i dan Malik. Alasannya adalah hadis riwayat Ibn Umar, yang tersurat bahwa benda wakaf tidak boleh dijual, dihibahkan, dan diwariskan.

Perubahan status, penggantian benda dan tujuan wakaf, sangat ketat pengaturannya dalam madzhab Syafi'i. namun demikian, berdasarkan keadan darurat dan prinsip mashlahah, di kalangan para ulama fiqh perubahan itu dalam dilakukan. Ini disandarkan pada pandangan agar manfaat wakaf itu tetap terus berlangsung sebagai sadaqah jariyah, tidak mubadzir karena rusak, tidak berfungsi lagi dan sebagainya. ${ }^{17}$

Imam Ahmad berpendapat bahwa boleh menjual benda wakaf atau menukarnya, menggantinya, memindahkannya, dan menggunakan hasil

${ }^{16}$ Tuti A. Najib \& Ridwan al-Makassary (ed.) (2006). Wakaf, Tuhan dan Agenda Kemanusiaan: Studi tentang Wakaf dalam Perspektif Sosial di Indonesia. (Jakarta: CRCS UIN Syahid), hlm. 39.

${ }^{17}$ Mohammad Daud Ali (1988). Sistem Ekonomi Islam, Zakat dan Wakaf. (Jakarta: UI Press), hlm. 93. 
penjualan tersebut untuk kemudian digunakan lagibagi kepentingan wakaf. Abu Yusuf, murid Hanafi, berpendapat bahwa benda wakaf tersebubt boleh dijual dan menggunakan hasil penjualan tersebut. Sedangkan Muhammad, murid Hanafi juga, berpendapat bahwa kalau benda wakaf tersebut sudah tidak berfungsi lagi atau rusak, maka benda tersebut kembali kepada pemilik pertama atau wakif. ${ }^{18}$

\section{Shighat (pernyataan atau ikrar wakif)}

Shighat atau ikrar adalah pernyataan penyerahan harta benda wakaf oleh wakif. Dalam hal ini perbedaan yang muncul adalah bentuk pernyataan apakah lisan, kinayah atau tindakan. Sementara dalam hal akad wakaf, semua madzhab menyatakan bahwa wakaf adalah akad tabarru' yaitu transaksi sepihak yang sah sebagai suatu akad yang tidak memerlukan kabul dari pihak penerima dan dicukupkan dengan ijab si wakif. Akad tidaklah menjadi syarat dalam akad wakaf. Definisi akad disini adalah suatu bentuk perbuatan hukum (tasharruf) yang mengakibatkan adanya kemestian penataan kepada apa yang dinyatakan dari kehendak perbuatan hukum itu oleh pihak yang berkepentingan, kendatipun pernyataan itu dari sepihak saja. Akad dalam pengertian kesepakatan dari dua belah pihak yang berkehendak melakukan suatu perikatan digambarkan dengan ijab dan qabul seperti yang terjadi dalam jual beli, sewa menyewa, dan sebagainya, sehingga tidaklah berlaku dalam pengertian akad wakaf. ${ }^{19}$

Di samping penjelasan tersebut di atas, al-Kabisi lebih dahulu mempertanyakan apakah wakaf termasuk akad yang menimbulkan tasharruf (perbuatan hukum) yang menimbulkan prestasi akibat hukum yang telah disetujui atau al-iqa' (pelimpahan) yang tidak menimbulkan akibat hukum, hanya pelimpahan atau penyerahan yang instrinsik di dalamnya adalah amanat dan tanggung jawab untuk menjalankannya. Ia cenderung berpendapat bahwa wakaf merupakan akad al-iqa' (pelimpahan) karena fokus wakaf adalah pendayagunaan yang sifatnya sosial dengan perspektif kebutuhan sosial juga, bukan kontraktual. $^{20}$

\section{Bentuk-bentuk wakaf}

\section{A. Wakaf Ahli}

Wakaf ahli yaitu wakaf yang ditujukan kepada orang-orang tertentu, seorang atau lebih, baik keluarga si wakif atau bukan. Wakaf ahli juga sering

${ }^{18}$ Sayyid Sabiq (1977). Fiqhu as-Sunnah. (Lebanon: Dar al-'Arabi), hlm. 387; Abil Mawahib bin Ahmad Abdul Wahab (t.t.). Mizan al-Kubro. (Mesir: Dar Ahya al-Kutub al-'Arabiyyah), hlm. 228.

${ }^{19}$ Abu Zahrah. Muhadharat fi al-Waqf, hlm. 51-52.

${ }^{20}$ Al-Kabisi. Hukum Wakaf, hlm. 95. 
disebut wakaf $d z u r r i$ atau wakaf 'alal aulad yakni wakaf yang diperuntukan bagi kepentingan dan jaminan sosial dalam lingkungan keluarga atau lingkungan kerabat sendiri. ${ }^{21}$

Dalam satu segi, wakaf abli ini mempunyai dua aspek kebaikan, yaitu (1) kebaikan sebagai amal ibadah wakaf, (2) kebaikan silaturrahmi terhadap keluarga yang diberikan harta wakaf. Namun, pada sisi lain wakaf abli sering menimbulkan masalah, seperti bagaimana jika keturunan yang ditunjuk sudah tidak ada lagi? Siapa yang berhak mengambil manfaat benda (harta wakaf) itu? Bagaimana jika keturunan si wakif berkembang sangat banyak sehingga menyulitkan pemerataan dalam pembagian hasil harta wakaf? Bagaimana bila keturunan wakif tidak bersedia lagi mengurus harta wakaf, siapa yang berwenang mengemban amanat untuk mengelola harta wakaf? Dan seterusnya.

\section{B. Wakaf Khoiri}

Wakaf khoiri yaitu wakaf yang secara tegas untuk kepentingan keagamaan atau kemasyarakatan (kepentingan umum). ${ }^{22}$ Wakaf ini ditujukan untuk kepentingan umum dengan tidak terbatas pada aspek penggunannya yang mencakup semua aspek untuk kepentingan dan kesejahteraan umat manusia pada umumnya. Kepentingan umum tersebut bisa untuk keagamaan, jaminan sosial, pendidikan, kesehatan, keamanan dan lain-lain, yang dapat berwujud seperti pembangunan masjid, sekolah, jembatan, rumah sakit, panti asuhan anak yatim dan sarana sosial lainnya.

Dari tinjauan penggunaannya, wakaf ini lebih banyak manfaatnya ketimbang wakaf abli, karena tidak terbatasnya pihak-pihak yang mengambil manfaat. Sesungguhnya jenis wakaf ini yang sesuai dengan hakikat wakaf dan secara substansial, wakaf ini juga merupakan salah satu cara membelanjakan (memanfaatkan) harta di jalan Allah.

\section{Wakaf: Tinjauan Hukum Nasional}

Pada sub ini lebih dikonsentrasi dengan menganalisis berbagai hal seputar wakaf berdasarkan UU No. 41 tahun 2004 tentang wakaf dan terkadang mengambil dari aturan hukum nasional lain dengan porsi seperlunya saja seperti Peraturan Pemerintah (PP) atau Instruksi Presiden (Inpres). Beberapa peraturan yang menaungi wakaf dimunculkan dalam tulisan ini, karena sesuai dengan bunyi pasal 70 UU No. 41 tahun 2004, bahwa:

"Semua peraturan perundang-undangan yang mengatur mengenai perwakafan masih tetap berlaku sepanjang tidak bertentangan dan/

\footnotetext{
${ }^{21}$ Sayyid Sabiq. Fiqhu as-Sunnah, hlm. 378.

${ }^{22}$ Ibid.
} 
atau belum diganti dengan peraturan yang baru berdasarkan undangundang ini”

Pembahasan ini diawali dengan pengertian, tetapi perlu diingat bahwa pengertian atau definisi wakaf secara institusional pun beraga. Keragaman definisi ini sebagai akibat dari perbedaan penafsiran terhadap institusi wakas sebagaimana yang dilakukan oleh para mujtahid dan yang pernah dipraktekkan, dan oleh masyarakat Islam.

Pada mulanya, definisi wakaf di Indonesia lebih cenderung kepada definisi yang dikemukakan oleh Syaf'iyah. PP No. 28 tahun 1977 tentang Perwakafan Tanah Milik, pasal 1 (1), berbunyi bahwa:

"Wakaf adalah perbuatan hukum seseorang atau badan hukum yang memisahkan sebagian dari harta kekayaannya yang berupa tanah milik dan melembagakannya untuk selama-lamanya untuk kepentingan peribadatan atau keperluan umum lainnya sesuai dengan ajaran Agama Islam".

Sementara dalam Inpres No. 1 tahun 1991 tentang Penyebarluasan Kompilasi Hukum Islam, pasal 215 (1), berbunyi bahwa:

"Wakaf adalah perbuatan hukum seseorang atau sekelompok orang atau badan hukum yang memisahkan sebagian dari harta benda miliknya dan melembagakannya untuk selama-lamanya untuk kepentingan ibadat atau keperluan umum lainnya sesuai dengan ajaran Islam".

Jika membandingkan keduanya antara PP No. 7 tahun 1977 dan Inpres No. 1 tahun 1999 terlihat pada jenis benda wakaf. Dalam PP disebutkan bahwa benda wakaf adalah tanah milik. Sedangkan dalam Inpres disebutkan bahwa benda wakaf adalah benda milik. Dalam Inpres menunjukkan bahwa benda yang dapat diwakafkan itu bukan saja hanya tanah milik, melainkan juga dapat berupa benda milik lainnya, yang menurut tafsir terhadap Inpres tersebut bisa benda tetap (tak bergerak) yang disebut al-aqr, atau benda bergerak yang disebut al-musya?.

Dinamika sosial, desakan publik dan perubahan paradigma berpikir yang semakin meluas memandang wakaf "memaksa" lahirnya UU No. 41 tentang wakaf sebagai payung hukum yang lebih kuat berskala nasional. UU tersebut mendefiniskan bahwa:

"Wakaf adalah perbuatan hukum wakif untuk memisahkan dan/atau menyerahkan sebagian harta benda miliknya untuk dimanfaatkan selamanya atau untuk jangka waktu tertentu sesuai dengan kepentingannya guna keperluan ibadah dan/atau kesejahteraan umum menurut syariah". ${ }^{23}$

Definisi ini tergolong definisi yang cukup longgar dan mengakomodasi perbedaan pendapat dikalangan ahli fiqh dan mempertimbangkan pengembangan

${ }^{23}$ UU No. 41 Tahun 2004 tentang Wakaf pasal 1 ayat (1). 
objek wakaf demi kemaslahatan umat. Beberapa catatan yang dapat dikemukakan adalah: (1) fleksibilitas bentuk objek wakaf dalam Inpres sebenarnya sudah mengakomodir semua pandangan ahli fiqh, tetapi tertutupi oleh pandangan hierarkhi terhadap pandangan hukum di Indonesia, bahwa Peraturan Pemerintah (PP) lebih tinggi dari pada Intruksi Presiden (Inpress), sehingga dengan lahirnya UU tersebut fleksibilitas tersebut lebih kuat payung hukumnya; (2) Kendala fanatisme madzhab yang kuat di akar rumput dalam meyakini objek wakaf adalah tanah (yang ia termasuk barang tak bergerak), sehingga implementasi belum berjalan mulus; (3) Durasi waktu dimunculkan mengakomodasi madzhab Maliki yang menafsirkan adanya wakaf temporal; (4) kata "keperluan umum" dirubah "kesejahteraan umum" mencerminkan sasaran final wakaf adalah masyarakat dapat menikmati wakaf sebagai salah satu media yang bisa mensejahterakannya; (5) kata "Agama Islam" atau "Islam" dirubah menjadi "Syariah". ${ }^{24}$

Dalam peraturan perundang-undangan (hukum nasional), unsur (rukun) wakaf tidak jauh berbeda dengan penambahan-penambahan tertentu. Mengenai wakif, syarat tidak jauh berbeda dengan uraian figh, hanya UU No. 41 tahun 2004 menambahkan syarat (1) tidak terhalang melakukan perbuatan hukum, dan (2) pemilik sah harta benda wakaf. ${ }^{25}$ Dua syarat tersebut diakomodasi dari berbagai pendapat ulama fiqh.

Dalam UU tidak menyebutkan kata muslim sebagai syarat wakif, sehingga non muslim pun bisa menjadi wakif. ${ }^{26}$. Pada tanggal 13 September 2004, Panitia Kerja Pembahasan RUU Wakaf yang terdiri dari Pemerintah dan DPR RI telah menyepakati untuk menghapus syarat "muslim" sebagai wakif. Penghapusan muslim sebagai syarat menjadi wakif bertujuan untuk menghindari sebuah paradoks, karena dalam sejarah Islam dan Hadis, bahwa wakaf yang diberikan oleh wakaf non muslim sah, artinya wakaf tersebut diterima. Hanya saja ada catatan bahwa wakaf yang diberikan oleh wakif non muslim hendaknya diarahkan untuk hal-hal yang terkait dengan

${ }^{24}$ Menurut Dawam Rahardjo, pengertian Syariah itu tidak identik dengan Syariah itu sendiri. Syariah dalam pengertian kedua adalah wahyu Tuhan itu sendiri dan Sunnah rasul yang pengertiannya sama dengan thariq, sabil, dan manhaj, yaitu jalan (way). Sedangkan Syariah dalam arti kedua masih memerlukan penjelasan dan interpretasi. Setelah berbentuk interpretasi dalam bentuk Syariah yang pertama, maka ia telah menjadi ilmu yang kebenarannya relatif dan karena itu beragam. Di sinilah Syariah yang pertama telah mengalami rasionalisasi menurut metode ilmiah. Hasilnya adalah konsep bank Syariah. Sementara istilah "bank Syariah" sendiri sebenarnya adalah khas Indonesia yang tidak dijumpai di negara-negara lain, yang seringnya dengan sebutan "bank Islam" (Islamic bank). Hal inilah yang menunjukkan bahwa bank Islam telah mengalami kontekstualisasi makna. Lihat M. Dawam Rahardjo (2004). "Menegakkan Syariat Islam di Bidang Ekonomi" dalam Adiwarman Azwar Karim. Bank Islam: Analisis Fiqib dan Keuangan. (Jakarta: Rajawali Press), hlm. xx.

${ }^{25}$ UU No. 41 Tahun 2004 tentang Wakaf pasal 8 ayat (1).

${ }^{26}$ Ibid. 
kemaslahatan umat bukan diperuntukan untuk tempat-tempat ibadah. ${ }^{27}$

Penghapusan syarat "muslim" tersebut dilakukan oleh Pemerintah dan DPR RI serta dari unsur agamawan diwakili oleh Majelis Ulama Indonesia (MUI). Untuk mencapai keputusan tersebut, tim tersebut telah melakukan penelitian tentang pendapat dari berbagai madzhab, yang kemudian ditemukan keterangan bahwa wakaf yang berasal dari non muslim itu bisa diterima. ${ }^{28}$

Sementara, pemaknaan istilah mauquf 'alaih sering disebutkan dengan istilah nadzir sebagai pelaksana dan pengelola wakaf. Secara spesifik dalam UU No. 41 tahun 2004, pemaknaan mauquf 'alaih dipisahkan lebih tegas dengan mencantumkan nadzir sebagai pengelola dan dengan tegas disebutkan peruntukan harta benda wakaf, yang konsekuensi menimbulkan ketatnya perubahan terhadap peruntukan harta wakaf di kemudian waktu. ${ }^{29}$

Disebutkan juga jangka waktu wakaf, unsur ini erat kaitannya dengan pendapat Imam Malik, yang memunculkan wakaf permanen dan wakaf temporal. Unsur jangka waktu ini muncul karena perluasan makna objek wakaf sehingga dibolehkannya wakaf harta bergerak seperti uang, yang dalam istilah modern penyalurannya dalam bentuk investasi.

Kembali ke konteks mauquf'alaih sebagai nadzir, ada beberapa hal yang harus dicermati, pertama, Nadzir non muslim. Dalam kasus nadzir non muslim, UU No. 41 tahun 2004 menegaskan bahwa nadzir harus muslim, pertimbangan adalah persoalan distribusi yang bermuara pada faktor politis keagamaan, termasuk di dalamnya nadzir yang berbentuk organisasi maupun badan hukum. Kedua, porsi konsumsi nadzir terhadap harta benda wakaf. berdasarkan. ${ }^{30}$ Berdasarkan hadis Umar ibn Khattab ra tentang wakaf tanah Khaibar diperkenankan nadzir mengkonsumsi hasil harta benda wakaf, hanya saja batasannya adalah: (1) tidak berlebih-lebihan, dan (2) tidak ada niat untuk menguasai (mengambil alih status kepemilikan). Dalam UU disebutkan porsi konsumsi adalah $10 \%$ dari hasil dari harta wakaf.

Mengenai benda wakaf, di Indonesia terjadi perluasan makna. Pada mulanya terbatas pada tanah yang termasuk kategori harta tak bergerak. Dalam UU No. 41

${ }^{27}$ Republika, Jum'at, 17 September 2004, "Panja RUU Wakaf sepakat, Non-Muslim bisa jadi Wakif".

${ }^{28}$ Ibid.

${ }^{29}$ Harta benda wakaf tidak boleh dijadikan jaminan, disita, dihibahkan, dijual, diwariskan, ditukar, atau dialihkan dalam bentuk hak lainnya. Terhadap harta benda wakaf yang ditukar baik status, fungsi dan fisiknya atas persetujuan Badan Wakaf Indonesia dengan salah satu pertimbangannya adalah kepentingan umum menyesuaikan Rencana Umum Tata Ruang (RUTR) sesuai dengan UU dan tidak bertentangan dengan syariah. UU No. 41 Tahun 2004 tentang Wakaf pasal 40, 41.

${ }^{30}$ Dalam melaksanakan tugas sebagaimana dimaksud dalam pasal 11, nadzir dapat menerima imbalan dari hasil bersih atas pengelolaan dan pengembangan harta benda wakaf yang besarnya tidak melebihi 10\% (sepuluh persen). UU No. 41 Tahun 2004 tentang Wakaf pasal 12. 
tahun $2004^{31}$ membolehkan wakaf dengan harta bergerak maupun harta tak bergerak. Kategori yang dijelaskan dalam undang-undang tersebut antara lain: (1) Benda Tidak bergerak, meliputi (a) hak atas tanah, (b) bangunan/ bagian bangunan yang berdiri di atas tanah tersebut, (c) tanaman/benda lain yang berkaitan dengan tanah, (d) hak milik atas satuan rumah susun, (e) benda tidak bergerak sesuai syariah dan UU; (2) Benda bergerak, seperti uang, logam mulia, surat berharga, kendaraan hak atas kekayaan intelektual, hak sewa dan benda bergerak sesuai syariah dan UU, termasuk mushaf, buku, kitab.

Dari segi akadnya, wakaf memang diakui sebagai akad sepihak dan termasuk akad tabarru', yang tidak membutuhkan qabul dari nadzir. Tetapi terhadap akad tersebut harus disikapi secara hati-hati Nadzir harus dilihat profil, komitmen, reputasi, kredibilitas, kapabilitas dan terpopuler adalah track record (rekam jejak) sehingga akuntabilitas publiknya dapat dipertanggungjawabkan. Hal terpenting pula terkait dengan akad adalah dimungkinkan timbulnya sengketa yang memerlukan pembuktian untuk keabsahan sehingga dipersyaratkan adanya (1) dokumen dan (2) saksi. Keduanya bukan menjadi rukun tetapi alat bukti yang harus ada dan dapat menguatkan keberadaan adanya akad (penyerahan) wakaf. Hal inilah yang sering terjadi di masyarakat, dan ini diduga adalah pengaruh madzhab Syafi'i. ${ }^{32}$

\section{F. Wakaf: Institusi Baru dalam Praktik}

\section{Badan Wakaf Indonesia (BWI)}

Badan Wakaf Indonesia (BWI) merupakan badan bentukan pemerintah untuk melakukan pembinaan dan pengawasan nadzir dan pengelolaan harta benda wakaf. Beberapa kasus terjadi misalnya, para nadzir baik perorangan maupun lembaga tidak bertanggung jawab atas harta benda wakaf yang dikelola, perubahan peruntukan harta benda wakaf dikarenakan -salah satunya- misalnya ada perubahan tata ruang kota, sehingga harus digusur atau dipindahkan. BWI diposisikan layaknya Badan Amil Zakat Nasional (BAZNAS) dalam hal zakat, namun hal yang masih diperdebatkan adalah mengenai status BWI, apakah struktural, koordinatif atau konsultatif. ${ }^{33}$

\footnotetext{
${ }^{31}$ UU No. 41 Tahun 2004 tentang Wakaf pasal 16.

${ }^{32}$ Juhaya S. Praja. Perwakafan di Indonesia, hlm. 3.

${ }^{33}$ Republika, Jum'at, 10 September 2004, "Menimbang Badan Wakaf Indonesia".
} 


\section{Lembaga Keuangan Syariah (LKS)}

Diakomodasinya wakaf dalam bentuk benda bergerak, geliat wakaf tunai menjadi marak dari perbincangan sampai ke aksi. Namun, masalah wakaf uang, amanat UU menyebutkan pengelola (nadzir) adalah HANYA lembaga keuangan syariah. Hal ini menimbulkan dua implikasi yang serius. Pertama, LKS adalah lembaga profit dan komersial, boleh jadi (dan kemungkinan besar) menggunakan dana wakaf menjadi suntikan dana likuiditas maupun dana investasi sektor riil, yang melupakan esensi dari wakaf uang untuk kemaslahatan dan kesejahteraan umat, kedua, tereduksinya potensi kemandirian dalam rangka pemberdayaan umat yang boleh jadi secara manajemen keuangan lebih baik dan akuntabel ketimbang LKS, sebagai contoh Dompet Dhuafa Republika, dan lembaga yang lain. ${ }^{34}$

\section{Sengketa Wakaf}

Penyelesaian sengketa wakaf ditempuh dengan beberapa tahapan yang dilakukan secara stratifikatif: ${ }^{35}$

1. Musyawarah untuk mencapai mufakat

2. Mediasi, (mediasi yang dimaksud adalah penyelesaian sengketa dengan bantuan pihak ketiga (mediator) yang disepakati oleh para pihak yang bersengketa).

3. Arbitrase (Arbitrase yang dimaksud adalah Badan Arbitrase Syariah Nasional (BASYARNAS))

Pengadilan (Pengadilan yang dimaksud adalah Pengandilan Agama (PA) atau Mahkamah Syari'iyah).

Terkait dengan persoalan sengketa wakaf, keberadaan dokumen (sertifikat) dan saksi menjadi persoalan terpenting yang tidak bisa diabaikan, mengingat kultur sosial yang mengatasnamakan ibadah (tabarru) semuanya serba lisan. Sengketa yang muncul kemudian -diharapkan tidak muncul- dapat mengajukan dokumen dan saksi sebagai alat bukti untuk menyelesaikan sengketa, meskipun proses penyelesaiannya mungkin tidak sederhana.

\section{Wakaf Tunai dalam Literatur Fiqh dan Implikasi Filantropi}

Dewasa ini, muncul perbincangan seputar wakaf tunai yang tidak lagi set back pada kajian fiqh semata, tetapi perbincangan lebih luas pada bagaimana institusi wakaf tidak hanya sebagai ritualitas keagamaan tetapi bisa menyentuh aspek kemanusiaan dengan memberdayakan potensinya untuk kesejahteraan

\footnotetext{
${ }^{34}$ Lihat Chaider S. Bamualim dan Irfan Abubakar. Revitalisasi Filantropi Islam.

${ }^{35}$ UU No. 41 Tahun 2004 tentang Wakaf pasal 62 dan penjelasannya.
} 
publik semaksimal mungkin. Dari situlah kemudian muncul ide pendekatan ekonomi dalam mengkaji wakaf, sehingga seluruh unsur wakaf harus diberdayakan produktivitasnya baik wakif, nadzir maupun objek wakafnya serta menata sistem administrasi sebagai wujud akuntabilitas dan transparansi sebagai tuntutan manajemen modern.

\section{A. Wakaf Tunai}

Wakaf tunai (cash waqf atau waqf al-nuqud) merupakan salah satu wakaf benda bergerak yang dispesifikasi berupa uang. ${ }^{36}$ Wakaf tunai adalah wakaf yang dilakukan seseorang, kelompok orang, lembaga atau badan hukum dalam bentuk uang tunai, termasuk dalam pengertian uang adalah surat berharga. ${ }^{37}$ Wakaf tunai merupakan bentuk wakaf produktif dengan mekanisme investasi dana wakaf dan menyalurkan hasil dari pokok modal yang diinvestasikan. Membandingkannya dengan wakaf tanah misalnya, wakaf tanah hanya dinikmati oleh masyarakat yang berdomisili di sekitar harta wakaf tersebut berada. Sementara masyarakat miskin berdomisili di berbagai tempat, sehingga dibutuhkan sumber pendanaan baru yang tidak terikat tempat dan wakatu. Sebab uang bersifat fleksibel dan tidak mengenal batas wilayah pendistribusian.

Dalam sejarahnya, wakaf tunai telah dijalankan sejak awal abad kedua hijriyah. Bukhari meriwayatkan bahwa Imam Az-Zuhri (w. 124 H.) salah seorang ulama terkemuka dan peletak dasar tadwin al-hadis telah menetapkan fatwa itu. Sebagaimana ditulis dalam Shahih Bukhari juz 9 halaman 330 sebagai berikut:

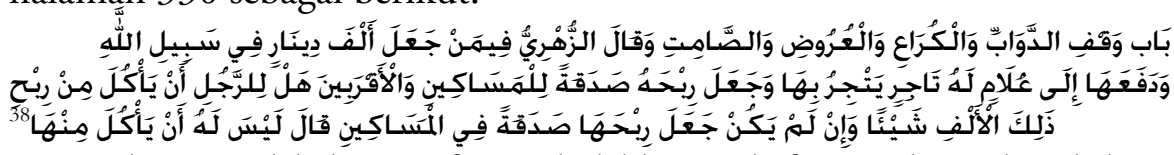

Ulama madzhab Hanafi membolehkan wakaf uang dinar dan dirham sebagai pengecualian atas dasar istihsan bi al-urf, berdasarkan atsar Abdullah ibn Mas'ud ra: "apa yang dipandang baik oleh kaum muslimin maka dalam pandangan Allah adalah baik, dan apa yang dipandang buruk oleh kaum muslimin maka pandangan Allah pun buruk". ${ }^{39}$ Hanya madzhab ini yang secara tegas membolehkan praktek wakaf tunai sebagai implikasi dari dibolehkannya wakaf benda bergerak secara tegas pula.

Di Indonesia, wakaf tunai (cash waqf) juga telah dikuatkan dengan diterbitkannya keputusan fatwa Majelis Ulama Indonesia tentang Wakaf Uang,

\footnotetext{
${ }^{36}$ UU No. 41 Tahun 2004 tentang Wakaf pasal 28-31.

${ }^{37}$ Fatwa Majelis Ulama Indonesia (MUI) tentang Wakaf Uang.

${ }^{38}$ Bukhari (t.t.). Shahih Bukhari. (Mesir: Dar al-Fikr al-Mu'ashir), Juz 9, hlm. 330.

${ }^{39}$ Wahbah Zuhaili. Al-Fiqh al-Islamiy, hlm. 162.
} 
yang pokok putusannya berisi: ${ }^{40}$

Wakaf uang (cash waqf atau waqf al-nuqud) adalah wakaf yang dilakukan seseorang, kelompok orang, lembaga atau badan hukum dalam bentuk uang tunai.

Termasuk ke dalam pengertian uang adalah surat-surat berharga. Wakaf uang hukumnya jawaz (boleh)

- Wakaf uang hanya boleh disalurkan dan digunakan untuk hal-hal yang dibolehkan secara syara

- Nilai pokok wakaf uang harus dijamin kelestariannya, tidak boleh dijual, dihibahkan, dan atau diwariskan.

- Terdapat beberapa aturan dalam wakaf benda bergerak berupa uang (wakaf tunai) antara lain:

- Wakaf tunai melalui lembaga keuangan syariah yang ditunjuk oleh Menteri

- Pernyataan kehendak wakif tentang wakaf tunai harus tertulis

- Lembaga keuangan syariah menerbitkan sertifikat wakaf uang yang disampaikan kepada wakif dan nadzir sebagai bukti penyerahan harta benda wakaf.

- Lembaga keuangan syariah atas nama nadzir mendaftarkan benda wakaf berupa uang kepada Menteri

Dari segi kemanfaatannya, menurut Antonio ${ }^{41}$, wakaf uang dewasa ini mempunyai empat manfaat utama, pertama, wakaf uang jumlahnya bisa bervariasi sehingg seseorang yang memiliki dana terbatas sudah bisa mulai memberikan dana wakafnya tanpa harus menunggu menjadi tuan tanah terlebih dahulu. Kedua, melalui wakaf uang, aset-aset yang berupa tanahtanah kosong bisa mulai dimanfaatkan dengan pembangunan gedung atau diolah untuk lahan pertanian. Ketiga, dana wakaf tunai juga bisa membantu sebagian lembaga-lembaga pendidikan Islam yang cash flow-nya terkadang kembang kempis dan menggaji civitas akademika alakadarnya. Keempat, pada gilirannya, Insya Allah, umat Islam dapat lebih mandiri dalam mengembangkan dunia pendidikan tanpa harus terlalu tergantung pada anggaran pendidikan negara yang memang semakin lama semakin terbatas.

Bila kemudian wakaf tunai hendak diterapkan dalam dunia pendidikan, masih menurut Antonio, ada tiga filosofi dasar yang harus ditekankan. Pertama, alokasi cash waqf harus dilihat dalam bingkai "proyek yang terintegrasi”, bukan bukan bagian-bagian dari biaya yang terpisah. Contohnya adalah anggapan dana wakaf akan habis bila dipakai untuk

\footnotetext{
${ }^{40}$ Fatwa Majelis Ulama Indonesia (MUI) tentang Wakaf Uang.

${ }^{41}$ Muhammad Syafii Antonio. "Kata Pengantar" dalam Al-Kabisi. Hukum Wakaf, hlm. xiv.
} 
membayar gaji guru atau upah bangunan, sementara wakaf harus abadi. Kedua, asas kesejahteraan nadzir. Sering kali nadzir diposisikan kerja asal-asalan atau lillahi ta'ala, sebagai akibatnya seringkali pula kinerja nadzir asal-asalan juga. Inilah saatnya menjadikan nadzir sebagai profesi yang memberikan kesejahteraan dan harapan masa depan. Ketiga, asas transparansi dan accountability, di mana badan wakaf dan lembaga yang membantunya harus melaporkan setiap tahun tentang proses pengelolaan dana kepada umat dalam bentuk audited financial report. ${ }^{42}$

Di dunia pendidikan, tidak dapat dipungkiri bahwa nama-nama lembaga Islam terkemuka seperti al-Azhar University Cairo, Universitas Zaituniyyah di Tunisia dan ribuan Madaris Imam Lisesi di Turki, Universitas Nizamiyah di Baghdad, dan lain sebagainya bukanlah lembaga pendidikan yang fully profit oriented. Mereka merupakan lembaga yang bercorak sosial. Secara operasional tidak mungkin lembaga tersebut akan bertahan hingga sekarang bila mengharapkan subsidi pemerintah, dan tidak mungkin hanya mengandalkan sumbangan masyarakat. Anehnya lembaga-lembaga tersebut bisa memberikan beasiswa bagi jutaan mahasiswa di seluruh dunia.

Di Indonesia, Pondok Modern Gontor Ponorogo, Badan Wakaf Universitas Islam Indonesia (UII) Yogyakarta, dan Pesantren Tebuireng Jombang, merupakan beberapa potret pelembagaan wakaf yang dikembangkan dalam bentuk investasi yang manfaatnya dipergunakan untuk pengembangan pendidikan. ${ }^{43}$ Tidak heran bila beberapa lembaga pendidikan yang berbasis wakaf di Indonesia tidak bisa berkembang mandiri dan selalu bergantung pada subsidi pemerintah dan donasi masyarakat. Hal ini memang tidak terlepas dari kendala-kendala yang melekat guna pengembangan wakaf tunai ke depan.

Kendala pengembangan wakaf tunai:

\section{State of mind}

Kuatnya pengaruh bahwa wakaf identik dengan wakaf harta benda tak bergerak khususnya tanah dan bangunan. Hal ini dipengaruhi oleh 2 aspek (1) keyakinan ajaran (madzhab) yang dianut yakni mayoritas madzhab Syafii, (2) budaya lokal (local culture/community image). Hal tersebut yang secara implikatif mempengaruhi proses sosialisasi konsep wakaf tunai pada masyarakat, apalagi masyarakat cenderung patuh terhadap figur ketika memutuskan untuk mengikuti sebuah ajaran keagamaan yang tergolong tidak familier. ${ }^{44}$ Juga terasa aneh kedengarannya, sadaqah yang sudah lazim berupa uang saja sulit untuk

${ }^{42}$ Ibid., hlm. xv.

${ }^{43}$ Chaidar S. Bamualim \& Irfan Abubakar (ed.). Revitalisasi Filantropi Islam, hlm. 217-296.

${ }^{44}$ Tim Penyusun Buku (2007). Strategi Pengembangan Wakaf Tunai di Indonesia. (Jakarta: Depag RI), hlm. 8-9. 
melaksanakan apalagi sadaqah atas nama wakaf berupa uang.

\section{Model pendayagunaan (peruntukan)}

Tidak mudah memang mengelola investasi untuk disalurkan pada sektor riil. Namun demikian bidang-bidang tertentu bisa dijadikan lahan untuk menyalurkan manfaat wakaf tunai agar bisa cepat dirasakan oleh masyarakat. Pendidikan, kesehatan, pelayanan sosial, usaha kecil menengah, dan bidangbidang potensial lainya bisa menjadi lahan garapan dalam pengembangan wakaf tunai, hanya saja kendala teknis di lapangan tidak mudah. Misalnya, dalam hal usaha kecil mikro, peruntukan dana wakaf sedianya untuk masyarakat kecil, namun sayangnya mereka tidak bisa menunjukkan kelayakan usaha yang hendak dibantu. Sasaran akhirnya adalah kemandirian, sementara atas nama wakaf, masyarakat selalu bergantung sebagai amal jariyah cuma-cuma. ${ }^{45}$

\section{Nadzir hanya Lembaga Keuangan Syariab}

Berdasarkan UU No. 41 tahun 2004, bahwa untuk kasus wakaf tunai nadzir yang diberi wewenang untuk mengelola adalah lembaga keuangan syariah yang ditunjuk oleh menteri. ${ }^{46}$ Pemerintah menyatakan bahwa pengelolaan wakaf tunai melalu lembaga keuangan syariah ini atas dasar pertimbangan keuangan. Mestinya penyerahan dan pengelolaan wakaf tunia tak hanya diserahkan kepada lembaga keuangan syariah, karena ada lembaga lain yang mampu mengelola wakaf tunai tersebut dengan profesional dan diyakini mampu menjaga keamanan wakaf. Ada dua hal yang dicermati dari penyerahan dan pengelolaan wakaf tunai oleh lembaga keuangan syariah, (1) lembaga keuangan syariah adalah lembaga profit dan komersial, ia juga harus memikirkan pendayagunaan sosial wakaf, yang ditakutkan adalah dana wakaf tersebut justru menyokong kegiatan komersialnya sendiri, sehingga bahwa wakaf itu harus diberikan manfaat ekonomi bagi umat, ddan (2) tereduksinya peran dan pemberdayaan masyarakat dalam hal-hal produktif, sementara intinya adalah kapabilitas, kredibilitas, profesionalitas dari nadzir, bukan status nadzir yang akan mengelola wakaf tunai. ${ }^{47}$

\section{Perangkat aturan bukum}

Sebagai acuan bertindak dalam masalah wakaf di Indonesia, UU No. 41 tahun 2004 belum memiliki aturan turunan dalam bentuk Peraturan Pemerintah (PP) sebagai petunjuk pelaksana (juklak) operasional. Beberapa pasal yang disebutkan bergantung pada kehadiran Peraturan Pemerintah, misalnya tentang

${ }^{45}$ Ibid., hlm. 72 .

${ }^{46}$ UU No. 41 Tahun 2004 tentang Wakaf pasal 28.

${ }^{47}$ Republika, Jum'at, 01 Oktober 2004, "Pengelolaan Wakaf Tunai Hanya oleh Lembaga Keuangan Syariah". 
detail mengenai ketentuan wakaf benda bergerak berupa uang. ${ }^{48}$ Namun demikian, spirit relijiusitas harus mengalahkan segalanya demi kepentingan sosial dan yang terpenting adalah prinsip kemaslahatan harus selalu dikedepankan, sesuai dengan koridor hukum yang berlaku.

\section{B. Wakaf produktif}

Perlunya rekonstruksi konsep fiqh wakaf, diamati oleh Uswatun Hasanah, staf pengajar Program Pascasarjana Fakultas Hukum Universitas Indonesia, didasarkan salah satunya pada pengelolaan wakaf di Indonesia yang sangat memprihatinkan. Ia menunjukkan bahwa karena faktor ketidakprofesionalan dalam penanganan harta benda wakaf, banyak yayasan pendidikan yang berasal dari harta benda wakaf terlantar. dan tidak berkembang atau bahkan "gulung tikar ". Yayasan semacam ini, di Indonesia jumlahnya sangat banyak. Inilah salah satu ide dasar munculnya istilah wakaf produktif.

Kesadaran masyarakat untuk mengamalkan tingkat religiusitasnya dengan cara wakaf memang cukup tinggi. Namun sayangnya, banyak aset wakaf yang tingkat pendayagunaannya stagnan, dan tidak sedikit yang tidak berkembang sama sekali. Penyebabnya adalah umat Islam pada umumnya mewakafkan tanah, namun kurang memikirkan biaya operasional sekolah, sehingga yang harus dilakukan adalah pengembangan wakaf produktif untuk mengatasi hal tersebut. Pilihan menganut manajemen modern menjadi niscaya dan harus dilakukan serta kelaziman bahwa harta benda wakaf adalah hanya harta benda tak bergerak harus segera diubah bahwa harta benda wakaf bergerak juga bisa diwakafkan dan potensial untuk dikembangkan. Keterikatan dengan pemahaman yang diyakini dan kualitas nadzir yang tidak futuristik dalam mengelola aset wakaf menyebabkan potensi harta wakaf tidak berkembang semestinya. ${ }^{49}$

Dua hal yang dilakukan adalah (1) manajemen kenadziran. Hal yang harus diperhatikan pula adalah profesionalitas nadzir, baik mengenai (1) kredibilitas terkait dengan kejujuran, (2) profesionalitas terkait dengan kapabilitas, maupun (3) kompensasi terkait dengan upah pendayagunan sebagai implikasi profesionalitasnya, (2) peruntukan aset wakaf. Kemungkinan alih fungsi (rubah peruntukan)dan relokasi menjadi kemestian yang harus dilakukan untuk pengembangan aset wakaf yang boleh jadi juga terpengaruh oleh mekanisme pasar yang mempengaruhi kebutuhan peruntukan aset wakaf agar lebih produktif.

Pengelolaan dan pengembangan harta benda wakaf dilakukan secara produktif dapat dilakukan dengan berbagai cara. Kategori produktif ${ }^{50}$ yang dapat dilakukan antara lain: cara pengumpulan, investasi, penanaman

\footnotetext{
${ }^{48}$ UU No. 41 Tahun 2004 tentang Wakaf pasal 31.

${ }^{49}$ Republika, 30 April 2004, "Perlu Rekonsepsi Fikih Wakaf".

${ }^{50}$ UU No. 41 Tahun 2004 tentang Wakaf pasal 43 ayat (2) dan penjelasannya.
} 
modal, produksi, kemitraan, perdagangan, agrobisnis, pertambangan, perundustrian, pengembangan teknologi, pembangunan gedung, apartemen, rumah susun, pasar swalayan, pertokoan, perkantoran, sarana pendidikan, sarana kesehatan, usaha-usaha yang tidak bertentangan dengan syariah.

Dalam hal pengelolaan dan pengembangan harta benda wakaf diperlukan penjamin, maka diperlukan lembaga penjamin syariah. ${ }^{51}$ Lembaga tersebut adalah badan hukum yang menyelenggarakan kegiatan penjamin atas suatu kegiatan usaha yang dapat dilakukan antara lain melalui skim asuransi syariah atau skim lainnya sesuai dengan ketentuan peraturan perundang-undangan yang berlaku.

Pengembangan dan pengelolaan fungsi aset wakaf secara produktif merupakan upaya menghidupkan kembali harta wakaf yang statis atau cenderung mati. Pengembangan wakaf ini juga bisa ditopang dengan dikembangkannya konsep wakaf tunai.

\section{Penutup}

Media filantropi dalam bentuk wakaf sejatinya harus segera membumi sehingga amanat UU dengan kata "kesejahteraan umum" yang menihilkan sekat keyakinan cepat terwujud. Untuk mewujudkannya sesegera mungkin dilakukan transformasi yang meliputi (1) transformasi paradigma relijiusitas dalam bentuk aksi yang diawali dengan tidak hanya statis pada keyakinan ajaran yang dipegangi tetapi dengan membuka horizon pemahaman yang lebih luas, (2) transformasi relijius menjadi aksi sosial, (3) transformasi harta tak bergerak diperluas untuk barang yang bergerak, (4) transformasi peruntukan yang stagnan menjadi dinamis ke arah produktif.

\section{DAFTAR PUSTAKA}

Abil Mawahib bin Ahmad Abdul Wahab (t.t.). Mizan al-Kubro. Mesir: Dar Ahya al-Kutub al-'Arabiyyah.

Abu Zahrah (1971). Muhadharat fi al-Waqf. Beirut: Dar al-Fikr al-'Arabi.

Akh. Minhaji (2005). "Nation State dan Implikasinya Terhadap Pemikiran dan Implementasi Hukum Wakaf", Kata Pengantar dalam Abdul Ghofur Anshori, Hukum dan Praktik Perwakafan di Indonesia. Yogyakarta: Pilar Media.

Al-Baijuri (t.t.). Hasyiyah al-Baijuri. Beirut: Dar al-Fikr, II.

Ali Fikri (1938). Al-Mu'amalat al-Maliyah wa al-Adabiyah. Mesir: Mushthafa

${ }^{51}$ Ibid., pasal 43 ayat (3) dan penjelasannya. 
al-Babi al-Halabi.

Asy-Syarbini (t.t.). Mugni al-Muhtaj. Kairo: Musthafa Halabi.

Bukhari (t.t.). Shahih Bukhari. Mesir: Dar al-Fikr al-Mu'ashir.

Chaidar S. Bamualim \& Irfan Abubakar (ed.) (2005). Revitalisasi Filantropi Islam: Studi Kasus Lembaga Zakat dan Wakaf di Indonesia. Jakarta: PBB UIN Syahid.

Fatwa Majelis Ulama Indonesia (MUI) tentang Wakaf Uang.

Harian Umum Republika.

Inpres No. 1 tahun 1999 tentang Kompilasi Hukum Islam.

Juhaya S. Praja (1995). Perwakafan di Indonesia: Sejarah, Pemikiran, Hukum dan Perkembangannya. Bandung: Yayasan Piara.

M. Dawam Rahardjo (2004). "Menegakkan Syariat Islam di Bidang Ekonomi" dalam Adiwarman Azwar Karim, Bank Islam: Analisis Fiqib dan Keuangan. Jakarta: Rajawali Press.

Mohammad Daud Ali (1988). Sistem Ekonomi Islam, Zakat dan Wakaf. Jakarta: UI Press.

Muhammad Abid Abdullah Al-Kabisi (2004). Hukum Wakaf: Kajian Kontemporer Pertama dan Terlengkap tentang Fungsi dan Pengelolaan Wakaf serta Penyelesaian atas Sengketa Wakaf, Terj. Ahrul Sani Faturrahman \& Rekan KMCP. Jakarta: Dompet Dhuafa Republika \& IIMaN.

Muhammad ibn Bakar ibn Mandzur al-Mishri $(1301 \mathrm{H})$. Lisan al-Arab. Bulaq: Al-Mishriyah, Jilid 11.

Muhammad Syafii Antonio (2004). "Kata Pengantar" dalam Muhammad Abid Abdullah Al-Kabisi, Hukum Wakaf: Kajian Kontemporer Pertama dan Terlengkap tentang Fungsi dan Pengelolaan Wakaf serta Penyelesaian atas Sengketa Wakaf, Terj. Ahrul Sani Faturrahman \& Rekan KMCP. Jakarta: Dompet Dhuafa Republika \& IIMaN.

Muslim (t.t.). Shahih Muslim. Mesir: Dar al-Fikr al-Mu'ashir.

Nawawi (t.t.). al-Raudhah. Beirut: Dar al-Kutub al-'Tlmiah, Juz IV.

PP No. 28 tahun 1977 tentang Perwakafan Tanah Milik

Sayyid Sabiq (1977). Fiqhu as-Sunnah. Lebanon: Dar al-'Arabi.

Tuti A. Najib \& Ridwan al-Makassary (ed.). (2006). Wakaf, Tuhan dan Agenda Kemanusiaan: Studi tentang Wakaf dalam Perspektif Sosial di Indonesia. Jakarta: CRCS UIN Syahid.

UU No. 41 Tahun 2004 tentang Wakaf

Wahbah Zuhaili (1985). Al-Figh al-Islamiy wa Adillatuhu. Mesir: Dar al-Fikr al-Mu'ashir. 